\title{
EVALUATION OF BIOMONITORING APPROACH TO STUDY LAKE CONTAMINATION BY ACCUMULATION OF TRACE ELEMENTS IN SELECTED AQUATIC MACROPHYTES: A CASE STUDY OF KANEWAL COMMUNITY RESERVE, GUJARAT, INDIA
}

\author{
J. I. NIRMAL KUMAR ${ }^{* 1}-$ H. SONI ${ }^{1}-$ R.N. KUMAR ${ }^{2}$ \\ ${ }^{I}$ Department of Environmental Sciences, Institute of Science \& Technology for Advanced \\ Studies \& Research (ISTAR), Vallabh Vidyanagar - 388 120, Gujarat, India \\ ${ }^{2}$ Department of Biosciences \& Environmental Sciences, N.V. Patel College of Pure \& Applied \\ Sciences, Vallabh Vidyanagar-388 120, Gujarat, India \\ e-mail: istares2005@yahoo.com
}

(Received $28^{\text {th }}$ November 2006; accepted $23^{\text {th }}$ July 2007)

\begin{abstract}
A biomonitoring study was carried out at Kanewal reservoir, an internationally important wetland listed in Asian Directory of Wetlands, designated as a "Wetland of National Importance" and a proposed community reserve of Gujarat State, India, to ascertain the degree of trace element contamination. The study focused on assessment of trace element contamination in certain aquatic macrophytes to be used as biomonitors, in comparison with water and sediments (abiotic monitor) for heavy metal pollution. Good information was provided by analyzing the roots, stems and leaves of native aquatic plants (biomonitors) represented by seven species: Eichhornia crassipes, Echinochloa colonum, Hydrilla verticillata, Ipomoea aquatica, Nelumbo nucifera, Typha angustata and Vallisneria spiralis, along with surface sediments and water, were analyzed for $\mathrm{Cd}, \mathrm{Co}, \mathrm{Cu}, \mathrm{Ni}, \mathrm{Pb}$ and $\mathrm{Zn}$ contamination. The highest concentrations of the trace elements were measured in Eichhornia crassipes and the lowest in Nelumbo nucifera. Based on the concentration and toxicity status observed in the lake's vegetation, the six metals are arranged in the following decreasing order: $\mathrm{Zn}>\mathrm{Cu}>\mathrm{Ni}>\mathrm{Cd}>\mathrm{Co}>\mathrm{Pb}$. Compared with the standard, normal and critical toxicity range in plants, the detected value of $\mathrm{Pb}$ falls within normal range, while that of other elements were within the critical range. However, $\mathrm{Zn}$ and $\mathrm{Cu}$ showed the highest concentration and alarming toxicity levels, which are considered as one of the most hazardous pollutants in Kanewal reservoir. Certain species of aquatic macrophytes are also proposed as biomonitors (and/or biofilters) such as Eichhornia crassipes and Typha angustata, which are the two most useful species in biomonitoring studies due to their ability to accumulate elements in high concentration in the roots and its availability throughout the year. The results showed the significant difference in accumulation of metals like $\mathrm{Zn}, \mathrm{Cu}$ and $\mathrm{Ni}$ in different plant organs, which showed more accumulation in roots than that of stems and leaves. High positive correlation between combinations of different metal pairs in plant's root, stem or leaf system was established.
\end{abstract}

Keywords: aquatic macrophytes, trace elements, lake contamination, Kanewal, Community Reserve $(K C R)$

\section{Introduction}

Biomonitoring has several advantages and is the most significant one in study of sublethal levels of bioaccumulated contaminants within the tissues of organisms, which indicate the net amount of pollutants integrated over a period of time (Lovett-Doust et al., 1994). Biomonitoring of pollutants uses some plants as accumulator species, which accumulate relatively large amounts of certain pollutants, even from much diluted solutions without obvious noxious effects (Ravera et al. 2003). It may be performed in two ways, based on the kind of sampled organisms: I) 'endemic', or native, organisms 
(passive biomonitoring) and ii) introduced organisms (active biomonitoring) (Chaphekar, 1991).

Direct discharge or wet and dry depositions of contaminants increase the concentrations of trace elements in aquatic systems, thus resulting in their accumulation in sediments (Bowmer, 1992; Sinicrope et al. 1992). Aquatic plants absorb elements through roots and/or shoots (Pip and Stepaniuk, 1992; Jackson, 1998). Various species show different behaviour regarding their ability to accumulate elements in roots, stems and/or leaves. Therefore, it is useful to identify the plant organ that absorbs the greatest amount of trace elements (St-Cyr and Campbell, 1994; Baldantoni et al. 2004). In aquatic systems, where pollutant inputs are discontinuous and pollutants are quickly diluted, analyses of plant tissues provide time-integrated information about the quality of the system (Baldantoni et al. 2005).

Rana and Nirmal Kumar (1988) observed heavy metal content through EDAX in certain sediments in Central Gujarat and noticed that Fe content was found highest in sediments of Undeva, followed by the presence of Si and Al. Nirmal Kumar et al. (1989) have investigated elemental composition of certain aquatic plants by Energy Dispersive Analysis of X-Ray (EDAX). High level of heavy metals such as Al, Si, Mn and Fe were found accumulated in Vallisneria spiralis, Hydrilla verticillata and Azolla pinnata. Nirmal Kumar and Rita N. Kumar (1997) have also studied elemental composition of certain economically important plants by EDAX. Studies on biomonitoring, distribution and characterization of heavy metals in vegetables collected from village agricultural fields and organic farms around Anand province, Gujarat, India, as well as common edible vegetables sold in market was also carried out (Nirmal Kumar et al. 2004).

As the macrophytes concentrate great amount of various substances (e.g. metals) and are consequently useful indicators of local pollution, the aim of the present study was to assess the toxicity status induced by six heavy metals $(\mathrm{Cd}, \mathrm{Co}, \mathrm{Cu}, \mathrm{Ni}, \mathrm{Pb}$ and $\mathrm{Zn})$ in aquatic plant parts (roots, stems, leaves) of seven selected native macrophytes (passive biomonitors) in comparison with sediment and water samples.

\section{Materials and methods}

\section{Kanewal Community Reserve (KCR)}

Kanewal Community Reserve (KCR) is located on $22^{0} 33^{\prime} \mathrm{N}$ latitude and $72^{0} 38^{\prime} \mathrm{E}$ longitude, falls in 4B Gujarat-Rajwara biotic province of the semi arid lands of Central Gujarat, India (Fig. 1). The reservoir occupies 1500 ha area, $15 \mathrm{~m} \mathrm{ASL}$, and is the principal source of food and fishing for local dependent communities of peripheral eight villages. It carries household sewage at little extent and agricultural run-off from surrounding village pockets from all directions. No industrial effluent enters into the lake. The temperature rises up to $37^{\circ} \mathrm{C}$ during the month of May and falls below $14^{\circ} \mathrm{C}$ in January. The average rainfall is about $900 \mathrm{~mm}$ concentrated in July to September. KCR harbours three islands in core area having 15 to 20 households comprising 50 to 60 human populations of Dafer and Fisherman communities. The water regime of the reservoir supports more than 180 species of aquatic birds with an average density of around 42,000 waterfowl during peak winter months (Van Der Ven 1987). The population estimation of the recorded waterfowl clearly signifies the lake as an internationally important wetland (Koning and Koning-Raat 1975; Scott 1989) and 'Wetland of National Importance' (MoEF 2005). Besides it is known to support 
abundant growth of aquatic vegetation of Hydrilla, Ipomoea and Typha spp. Accordingly, it is one of the proposed Community Reserve by GSFD (2005). It is also identified as one of the important wetlands for evolving management action plan by the National Wetland Committee. Due to human interference, considerable changes occurred in its geomorphology, hydrological regime and biotic composition in recent past.

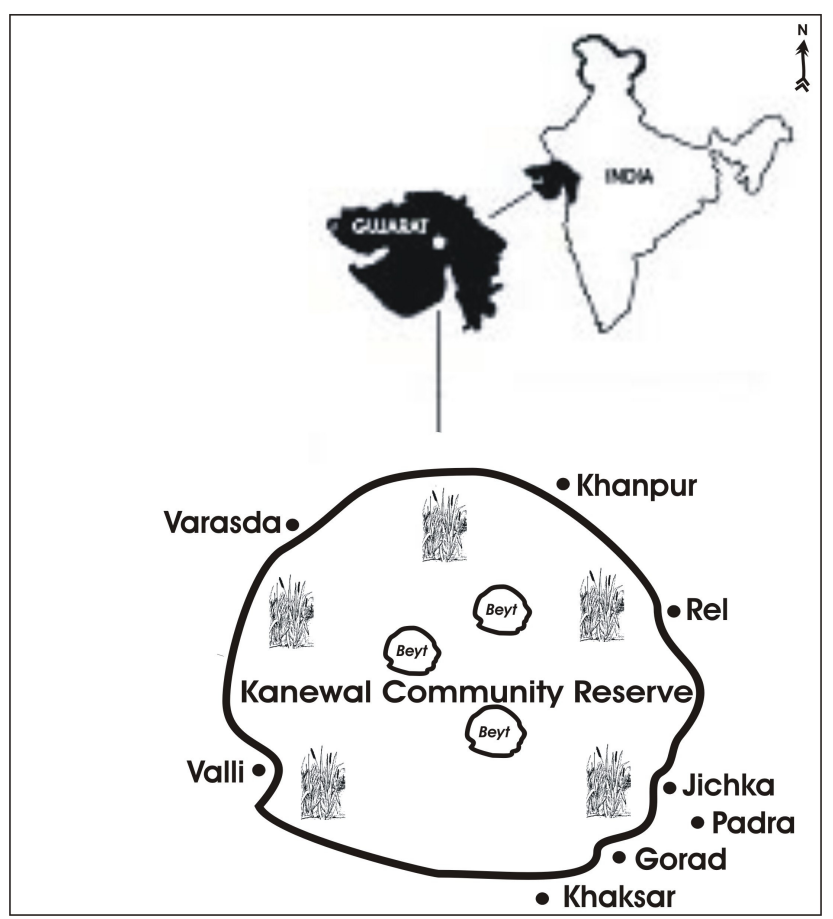

Figure 1. Location map of Kanewal Community Reserve (KCR)

\section{Water and sediment sampling}

Surface water and composite sediment samples were collected at random from different areas of the lake, covering all directions. Soon after collection, the water samples were filtered through $0.45 \mu \mathrm{m}$ (pore size) Millipore filter and preserved in plastic bottles by the addition of a few drops of nitric acid, while sediment samples were preserved in air-dry plastic bags. The samples were labelled carefully and brought to the laboratory for further analysis.

\section{Plant sampling}

Seven selected native aquatic macrophytes from the lake as passive biomonitors for estimating the toxicity status induced by six heavy metals $(\mathrm{Cd}, \mathrm{Co}, \mathrm{Cu}, \mathrm{Ni}, \mathrm{Pb}$ and $\mathrm{Zn}$ ) were collected in November 2004. The plant species selected were: Eichhornia crassipes, (Mart.) Solms, Echinochloa colonum (L.) Link, Hydrilla verticillata (L.f.) Royle, Ipomoea aquatica Forsk., Nelumbo nucifera Gaerth., Typha angustata Bory \& Chaub and Vallisneria spiralis L. Healthy aquatic plants were collected, washed with lake water to remove periphyton and sediment particles. Therefore, the element concentrations in the plant parts refer not only to tissue concentrations but also to adsorbed elements on part surfaces. The collected plant species were placed in plastic bags, labelled carefully and brought to the laboratory. Polythene tools were used in 
sampling and storing the collected matrices to avoid the metal contamination. Plant species were identified according to Shah (1978).

\section{Chemical analysis of water, soil and plant samples}

Soil samples were air-dried, sieved through $2 \mathrm{~mm}$ governorates sieve and kept for analyses. Each aquatic plant species sorted into different parts: roots, stems and leaves. The $50 \mathrm{gm}$ of each fresh sample dried at $80^{\circ} \mathrm{C}$ in hot air oven for $48 \mathrm{hrs}$. The samples of water, sediment and plant-parts were chemically analyzed for detection of heavy metals $(\mathrm{Cd}, \mathrm{Co}, \mathrm{Cu}, \mathrm{Ni}, \mathrm{Pb}$ and $\mathrm{Zn})$. Accurately 0.5 gram of dry powder of each sample was weighed, and digested with con.HNO3, $\mathrm{H}_{2} \mathrm{SO}_{4}$ and $\mathrm{H}_{2} \mathrm{O}_{2}$ (2:6:6) as prescribed by Saison et al. (2004). Towards the end of the digestion, the flasks were brought to near dryness. The solutions were made to $20 \mathrm{ml}$ each in a measuring cylinder with deionized water. The blanks were run with set, and the samples were analysed in Inductive Coupled Plasma Analyzer (ICPA) (Perkin-Elmer ICP Optima 3300 RL, U.S.A.) at Sophisticated Instrumentation Center for Applied Research and Testing (SICART), Vallabh Vidyanagar, Gujarat. The concentration of heavy metals such as $\mathrm{Cd}, \mathrm{Co}, \mathrm{Cu}$, $\mathrm{Ni}, \mathrm{Pb}$ and $\mathrm{Zn}$ was analyzed and calculated in ppm. Mean values of duplicate subsamples of the water, soil and plant samples were considered.

\section{Data analysis}

The mean values of heavy metals were calculated for water, soil and plant samples. The unilateral F-test was carried out between heavy metal contents in roots, stems and leaves to check if significant differences exist between the accumulation rate of each metal and different plant parts. Pearson correlation coefficient analysis was done between metal-pairs in plants to check if differences exist between different metal combinations in either root, stem or leaf system. The products of the correlation coefficient (r) were evaluated as follows:

- 0-0.3: No correlation;

- 0.3-0.5: Low correlation;

- 0.5-0.7: Medium correlation;

- 0.7-0.9: High correlation;

- 0.9-1.0: Very high correlation

The comparison of the concentration of an element in an aquatic organism with that of the same element in the water in which the organism lives. This is the ratio between the concentration of the element in the organism and that in the water, known as Concentration Factor (De Bortoli et al. 1968). The Concentration Factor (C.F.) was also calculated. When the C.F. value is at equilibrium, the release rate of the element from the organism is equivalent to its intake rate, so that the element concentration in the organism is fairly constant. 


\section{Results}

\section{Water and sediments}

The concentrations of the elements considered were far higher in the sediments than those calculated for the same elements in the lake water filtered through Millipore filter (0.45 $\mu \mathrm{m}$ opening size). Of the elements analyzed $\mathrm{Zn}$ was the most abundant both in sediments (1012.43 ppm) and water (201.16 ppm), followed by Cd with a concentration of $66.40 \mathrm{ppm}$ in the sediments and $1.81 \mathrm{ppm}$ in the water. Other metals $\mathrm{(Ni}, \mathrm{Cu}, \mathrm{Co}$ and $\mathrm{Pb}$ ) exhibit the receding trend in both sediments and water. The values of the ratio between element concentrations in the sediments and those in the water were lower (1.28-36.70) for $\mathrm{Pb}, \mathrm{Zn}, \mathrm{Cu}, \mathrm{Ni}$ and $\mathrm{Cd}$, whereas that of $\mathrm{Co}$ was observed high (26.36 ppm) (Table 1, Fig. 2).

Table 1. Element concentration in sediments and water and ratios between the concentrations in the sediments and that in the water.

\begin{tabular}{cccc}
\hline & $\begin{array}{c}\text { Sediment } \\
(\mathrm{ppm})\end{array}$ & $\begin{array}{c}\text { Water } \\
(\mathrm{ppm})\end{array}$ & Sediment/Water \\
\hline $\mathrm{Cd}$ & 66.40 & 1.81 & 36.70 \\
$\mathrm{Co}$ & 26.29 & 0.47 & 56.36 \\
$\mathrm{Cu}$ & 47.73 & 4.84 & 9.87 \\
$\mathrm{Ni}$ & 50.47 & 3.88 & 13.01 \\
$\mathrm{~Pb}$ & 8.01 & 6.27 & 1.28 \\
$\mathrm{Zn}$ & 1012.43 & 201.16 & 5.03 \\
\hline
\end{tabular}

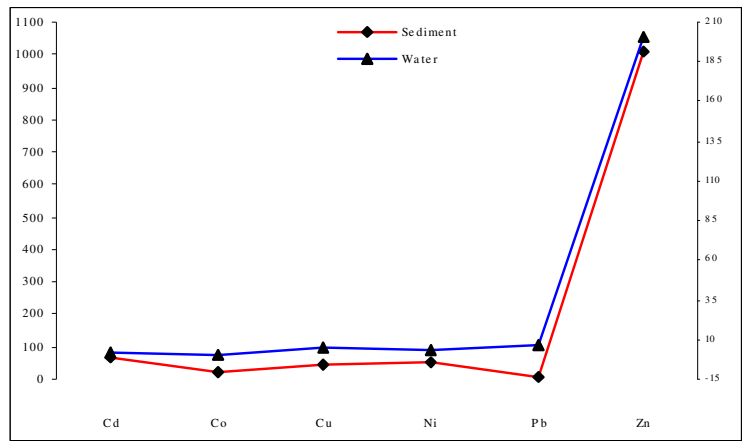

Figure 2. Mean concentration (ppm) of six heavy metals in water and sediment samples from $K C R$

\section{Macrophytes}

Table 2 shows the values of concentration of six elements in seven species of macrophytes. The mean concentration values of the elements in the plants decrease according to this sequence: $\mathrm{Zn}>\mathrm{Cu}>\mathrm{Ni}>\mathrm{Cd}>\mathrm{Co}>\mathrm{Pb}$. E. crassipes has the greatest capacity for concentrating trace elements with highest concentration $(502.19 \mathrm{ppm})$ of $\mathrm{Zn}$ and lowest concentration of $\mathrm{Cd}(0.43 \mathrm{ppm})$ followed by $V$. spiralis, $T$. angustata, $I$. aquatica, E. colonum and $H$. verticillata.. Conversely, $N$. nucifera has the lowest 
amount of trace element concentration with high amount of $\mathrm{Zn}(128.27 \mathrm{ppm})$ and low Co content (0.69 ppm).

Table 3 gives values of Concentration Factor (C.F.) for each species and element. The mean C.F. value of the elements in the plants decrease according to this sequence: $\mathrm{Zn}>\mathrm{Cu}>\mathrm{Pb}>\mathrm{Ni}>\mathrm{Cd}>\mathrm{Co}$. This sequence (which is rather different from that of the mean concentrations of elements in the plants) reflects the capacity of the macrophytes to accumulate elements independently from their concentration in the water that is the regulation capacity of the plants. Mean concentration factor for the various elements calculated for E. colonum are generally rather high, followed by $T$. angustata and $V$. spiralis, while those for $N$. nucifera and $H$. verticillata are lower than those of the other species. The higher men C.F. value for elements like $\mathrm{Cu}, \mathrm{Ni}$ and $\mathrm{Pb}$ was found in $V$. spiralis, while high content of $\mathrm{Cd}$, $\mathrm{Co}$ and $\mathrm{Zn}$ were observed in $H$. verticillata, $E$. colonum and E. crassipes, respectively.

Table 2. Mean element concentration (ppm) in certain macrophyte species.

\begin{tabular}{cccccccc}
\hline $\begin{array}{c}\text { Element/ } \\
\text { Taxon }\end{array}$ & $\mathrm{Cd}$ & $\mathrm{Co}$ & $\mathrm{Cu}$ & $\mathrm{Ni}$ & $\mathrm{Pb}$ & $\mathrm{Zn}$ & Mean \\
\hline Eichhornia crassipes & 0.43 & 6.33 & 19.10 & 38.79 & 5.87 & 502.19 & 95.45 \\
Echinochloa colonum & 20.03 & 14.48 & 41.36 & 22.94 & 4.24 & 169.36 & 45.40 \\
Hydrilla verticillata & 40.00 & 6.45 & 17.65 & 14.26 & 1.37 & 160.17 & 39.98 \\
Ipomoea aquatica & 14.11 & 6.34 & 64.83 & 11.47 & 2.34 & 243.57 & 57.11 \\
Nelumbo nucifera & 3.48 & 0.69 & 14.23 & 7.75 & 3.75 & 128.27 & 26.36 \\
Typha angustata & 0.23 & 13.59 & 49.98 & 24.69 & 6.35 & 274.40 & 61.54 \\
Vallisneria spiralis & 0.97 & 13.35 & 137.47 & 65.99 & 8.36 & 178.98 & 67.52 \\
& & & & & & & \\
Mean & 11.32 & 8.75 & 49.23 & 26.55 & 4.61 & 236.71 & \\
SD & 14.81 & 5.15 & 43.25 & 20.22 & 2.42 & 127.43 & \\
\hline
\end{tabular}

Table 3. Concentration factor calculated for the various species and elements.

\begin{tabular}{cccccccc}
\hline $\begin{array}{c}\text { Element/ } \\
\text { Taxon }\end{array}$ & $\mathrm{Cd}$ & $\mathrm{Co}$ & $\mathrm{Cu}$ & $\mathrm{Ni}$ & $\mathrm{Pb}$ & $\mathrm{Zn}$ & Mean \\
\hline Eichhornia crassipes & 0.01 & 0.11 & 1.94 & 2.98 & 4.58 & 99.84 & 18.24 \\
Echinochloa colonum & 0.55 & 0.26 & 4.19 & 1.76 & 3.32 & 33.67 & 7.29 \\
Hydrilla verticillata & 1.09 & 0.11 & 1.79 & 1.10 & 1.07 & 31.84 & 6.17 \\
Ipomoea aquatica & 0.38 & 0.11 & 6.57 & 0.88 & 1.83 & 48.42 & 9.70 \\
Nelumbo nucifera & 0.09 & 0.01 & 1.44 & 0.60 & 2.93 & 25.50 & 5.10 \\
Typha angustata & 0.01 & 0.24 & 5.06 & 1.90 & 4.96 & 54.55 & 11.12 \\
Vallisneria spiralis & 0.03 & 0.24 & 13.93 & 5.07 & 6.53 & 35.58 & 10.23 \\
& & & & & & & \\
Mean & 0.31 & 0.16 & 4.99 & 2.04 & 3.60 & 47.06 & \\
SD & 0.40 & 0.09 & 4.38 & 1.55 & 1.89 & 25.33 & \\
\hline
\end{tabular}

\section{Heavy metal pollution in plants}

The principal source of contamination in KCR is agricultural run-off coming through several drains along with washing and bathing activities from peripheral villages from all directions. Heavy metals are the most dangerous contaminants since they are persistent and accumulate in water, sediments and into tissues of the living organisms, 
through two mechanisms, namely 'bioconcentration' (uptake from the ambient environment and 'biomagnification' (uptake through the food chain) (Chaphekar, 1991). The results of the present study include assessment of six heavy metals $(\mathrm{Cd}, \mathrm{Co}, \mathrm{Cu}, \mathrm{Ni}$, $\mathrm{Pb}$ and $\mathrm{Zn}$ ) and evaluation of their toxicity status in different plant parts of five native aquatic plant species (Figs. 3, 4, 5).

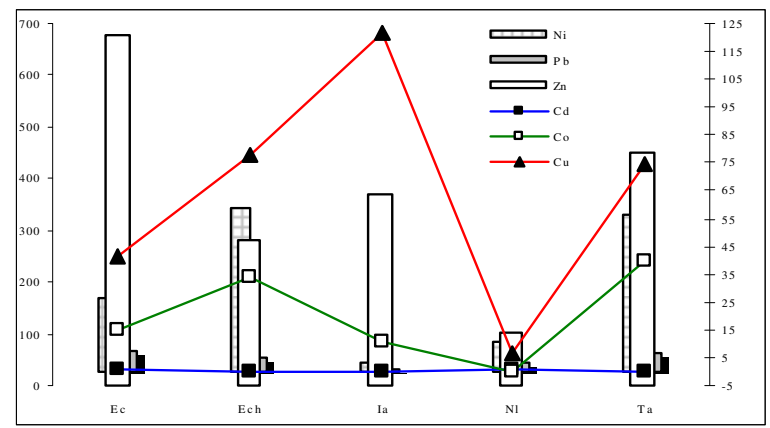

Figure 3. Mean concentration (ppm) of six heavy metals in roots of five plant species from KCR $(E c=$ Eichhornia crassipes, Ech= Echinochloa colonum, Ia= Ipomoea aquatica, $N l=N e l u m b o$ nucifera, Ta $=$ Typha angustata)

The heavy metal content in root system of five native aquatic macrophytes is exhibited by high concntration of $\mathrm{Zn}(675.56 \mathrm{ppm})$ in $E$. crassipes, and low amount of Co $(0.16 \mathrm{ppm})$ in $N$. nucifera. The roots of $E$. crassipes contained lowest Cd content (0.87 ppm), while the roots of T. angustata were found to contain high values of $\mathrm{Zn}$ $(450.34 \mathrm{ppm})$ and low $\mathrm{Cd}$ content $(0.20 \mathrm{ppm})$. This trend is followed by high concentration of $\mathrm{Zn}(370.78 \mathrm{ppm})$ and low content of $\mathrm{Cd}(0.25 \mathrm{ppm})$ in roots of $I$. aquatica. Besides, root system of E. colonum showed high content of $\mathrm{Zn}(281.30 \mathrm{ppm})$ and low Cd content (0.19 ppm). However, low values of $\mathrm{Zn}(100.98 \mathrm{ppm})$ were recorded in roots of $N$. nucifera.

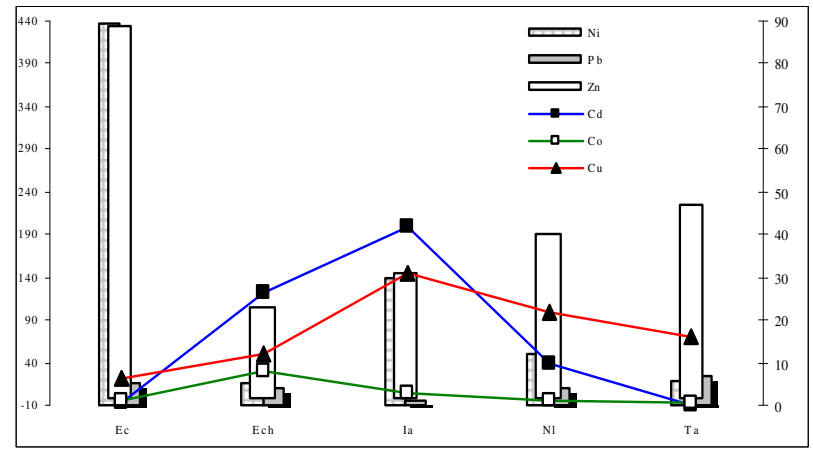

Figure 4. Mean concentration (ppm) of six heavy metals in stems of five plant species from $K C R(E c=$ Eichhornia crassipes, Ech = Echinochloa colonum, Ia = Ipomoea aquatica, $\mathrm{Nl}=$ Nelumbo nucifera, Ta= Typha angustata)

The mean concentration of heavy metal of stems of five aquatic plants varies from species to species. The high concentration of $\mathrm{Zn}$ and $\mathrm{Ni}, \mathrm{Co}, \mathrm{Cd}$ and $\mathrm{Cu}$ and $\mathrm{Pb}$ were high in E. crassipes, E. colonum, I. aquatica and T. angustata, respectively. 


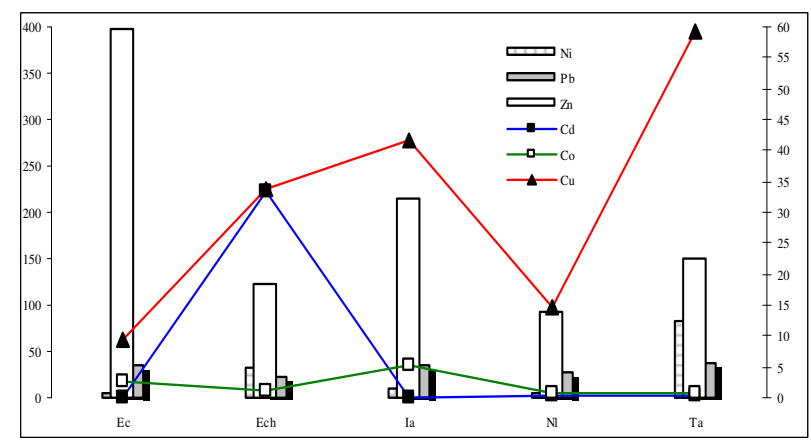

Figure 5. Mean concentration (ppm) of six heavy metals in leaves of five plant species from $K C R(E c=$ Eichhornia crassipes, Ech = Echinochloa colonum, Ia= Ipomoea aquatica, $\mathrm{Nl}=$ Nelumbo nucifera, Ta $=$ Typha angustata)

The mean concentration of six heavy metals fluctuates in different leaves of aquatic macrophytes. In E. crassipes, E. colonum, I. aquatica and T. angustata have high amount of heavy metals such as $\mathrm{Zn}, \mathrm{Cd}$ and $\mathrm{Cu}, \mathrm{Co}$ and $\mathrm{Pb}$ and $\mathrm{Ni}$, respectively. However, heavy metals found lowest in $N$. nucifera.

The chemical analysis for roots, stems and leaves of aquatic native plants: $E$. crassipes, E. colonum, I. aquatica, $N$. nucifera, $T$. angustata from KCR was carried out. However, $H$. verticillata and $V$. spiralis were analysed intact without sorted into different parts due to their incoherent phenophases. All the selected aquatic macrophytes were collected mostly from all directions of KCR from at least $0.5 \mathrm{~m}$ depth. Compared to the standard, normal and critical toxicity range of metals in all selected plants, the concentration of $\mathrm{Pb}$ was observed within normal range, while that of other elements were registered within the critical range. However, $\mathrm{Zn}$ and $\mathrm{Cu}$ showed the highest concentration and alarming toxicity levels, which is considered as one of the most hazardous pollutants in KCR (Table 4).

Table 4. Ranges of heavy metals contents and toxicity status in the tested plant species, compared with normal and critical ranges in plants

\begin{tabular}{ccccc}
\hline Metal & $\begin{array}{c}\text { Mean Range in } \\
\text { tested plants } \\
(\mathrm{ppm})\end{array}$ & $\begin{array}{c}\text { Normal } \\
\text { range in } \\
\text { plants } \\
(\mathrm{ppm})^{*}\end{array}$ & $\begin{array}{c}\text { Critical } \\
\text { range in } \\
\text { plants } \\
(\mathrm{ppm}) *\end{array}$ & $\begin{array}{c}\text { Toxicity } \\
\text { status }\end{array}$ \\
\hline $\mathrm{Cd}$ & $0.06-33.30$ & $0.1-2.4$ & $10-30$ & Critical \\
$\mathrm{Co}$ & $0.16-39.42$ & $0.75-1.07$ & $1-8$ & Critical \\
$\mathrm{Cu}$ & $6.48-121.88$ & $7.53-8.44$ & $25-90$ & Critical \\
$\mathrm{Ni}$ & $0.70-89.40$ & $0.89-2.04$ & $10-50$ & Critical \\
$\mathrm{Pb}$ & $0.86-7.32$ & $0.2-20$ & $30-300$ & Normal \\
$\mathrm{Zn}$ & $92.98-675.56$ & $1-400$ & $100-400$ & Critical \\
\hline \multicolumn{5}{c}{ Data after Kabata-Pendias and Pendias (1992) }
\end{tabular}

Comparing with standard normal range in plants, the mean concentration of $\mathrm{Pb}$ falls within the normal range $(0.86-7.32 \mathrm{ppm})$, whereas mean concentration of $\mathrm{Cd}(0.06$ $33.30 \mathrm{ppm}), \mathrm{Co}(0.16-39.42 \mathrm{ppm}), \mathrm{Ni}(0.70-89.40 \mathrm{ppm}), \mathrm{Cu}(6.48-121.88 \mathrm{ppm})$ and $\mathrm{Zn}$ (92.98-675.56 ppm) was recorded within critical ranges. Compared with the standard critical range of $\mathrm{Zn}(100-400 \mathrm{ppm})$, a critical amount (675.56 ppm) existed in roots, stems and leaves of E. crassipes. Thus $\mathrm{Zn}$ seems to be the most epidemic and hazardous 
pollutant in KCR, since it reached extremely high concentrations and may cause serious toxicity in most of the plant species.

\section{Accumulation pattern of heavy metals in root, stem and leaf systems}

Applying unilateral F-test on the concentrations of each metal (separately in roots against stems and leaves), indicated significant differences only for $\mathrm{Cd}$ and $\mathrm{Co}(\mathrm{p}<0.05)$ as follows:

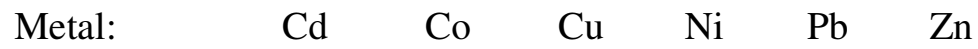

$$
\begin{aligned}
& \text { F-value: } \quad \begin{array}{lllllll}
0.000^{*} & 0.007^{*} & 0.012 & 0.538 & 0.669 & 0.353
\end{array}
\end{aligned}
$$

Based on the above results, it is obvious that Cadmium and Cobalt seems to accumulate with more tendencies towards roots than stems and leaves of the tested species.

The output of Pearson correlation coefficient (r) analysis on combinations of different metal-pairs which are present together in either roots, stems or leaves of the tested plant species showed medium + ve correlation $(r=0.5-0.7)$ between two metal pairs $(\mathrm{Zn}$ and $\mathrm{Pb} ; \mathrm{Ni}$ and $\mathrm{Pb})$ and high + ve correlation $(\mathrm{r}=0.7-0.9)$ between only a single metal pair ( $\mathrm{Ni}$ and $\mathrm{Zn}$ ) (Table 5). These results indicated that both roots and stem systems may have a kind of natural controlling mechanism regarding the quantity of specific metals taken from the ambient environment, but they don't have controlling mechanism to suppress the combination between specific metal pairs in their tissues (Ravera et al. 2003).

Table 5. Correlation coefficient between concentrations of heavy metal-pairs in root, stem and leaf systems of plant species

\begin{tabular}{cccc}
\hline \multirow{2}{*}{$\begin{array}{c}\text { Analysis } \\
\text { metal-pair }\end{array}$} & \multicolumn{3}{c}{ Correlation Coefficient $(\mathbf{r})$} \\
\cline { 2 - 4 } & Root system & Stem system & Leaf system \\
\hline $\mathrm{Zn} \times \mathrm{Cd}$ & 0.860 & 0.411 & -0.111 \\
$\mathrm{Cu} \times \mathrm{Cd}$ & 0.987 & -0.360 & -0.171 \\
$\mathrm{Ni} \times \mathrm{Cd}$ & 0.791 & 0.713 & -0.179 \\
$\mathrm{Ni} \times \mathrm{Zn} * *$ & 0.635 & 0.798 & 0.479 \\
$\mathrm{Co} \times \mathrm{Cd}$ & 0.422 & 0.151 & -0.059 \\
$\mathrm{~Pb} \times \mathrm{Cd}$ & 0.136 & 0.851 & -0.422 \\
$\mathrm{Zn} \times \mathrm{Cu}$ & 0.887 & -0.140 & -0.200 \\
$\mathrm{Zn} \times \mathrm{Co}$ & 0.512 & -0.063 & -0.291 \\
$\mathrm{Zn} \times \mathrm{Pb} * *$ & 0.392 & 0.175 & 0.873 \\
$\mathrm{Cu} \times \mathrm{Ni} * *$ & 0.719 & 0.023 & 0.742 \\
$\mathrm{Cu} \times \mathrm{Co} *$ & 0.349 & 0.400 & 0.617 \\
$\mathrm{Cu} \times \mathrm{Pb}$ & 0.284 & -0.047 & -0.119 \\
$\mathrm{Ni} \times \mathrm{Co} * *$ & 0.822 & 0.441 & 0.497 \\
$\mathrm{Ni} \times \mathrm{Pb}$ & -0.103 & 0.708 & 0.521 \\
$\mathrm{Co} \times \mathrm{Pb}$ & -0.100 & 0.631 & 0.050 \\
\hline $\mathrm{Medium} \mathrm{Correlation}(\mathrm{r}=0.5-0.7), * *$ High Correlation $(\mathrm{r}=0.7-0.9)$
\end{tabular}

Study reflects the transport mechanism of metals from abiotic environment (soil) to biotic environment (macrophyte) and their accumulation in various parts of aquatic plants. The transport mechanism and accumulation pattern of heavy metals (mean 
concentration) can be elaborated as follows: Sediment $>$ Root system $>$ Stem system $>$ Leaf system (Fig. 6).

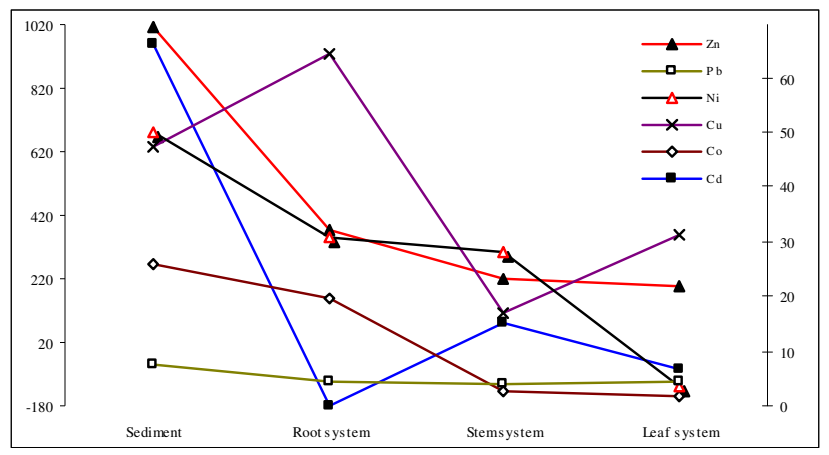

Figure 6. Mean concentration (ppm) of six heavy metals in sediment and plan parts from KCR

The overall study exhibits the highest mean concentration of $\mathrm{Zn}(450.78 \mathrm{ppm})$, followed by $\mathrm{Cu}$ (40.36), $\mathrm{Ni}$ (28.46), $\mathrm{Cd}$ (22.34), $\mathrm{Co}$ (12.79) and $\mathrm{Pb}$ (5.38), while the mean concentration of trace elements was observed high in sediment (201.89 ppm), followed by roots system (82.69), stem (48.02) and leaf (40.81). The information of metals versus species (arranged in a decreasing order) containing metals higher than the minimum critical limits (Kabata-Pendias and Pendias, 1992) is as follows:

Zn (Echhornia $>$ Typha $>$ Ipomoea $)$

$\mathrm{Cu}$ (Vellisnaria $>$ Ipomoea $>$ Nymphea)

$\mathrm{Ni}$ (Vellisnaria $>$ Eichhornia $>$ Typha)

\section{Discussion}

The aquatic plants in the present study exhibit different trace element concentrations, depending on the plant organ. Roots of aquatic plants absorb heavy metals from the sediments and accumulate high concentrations (Baldantoni et al. 2004). Similarly our findings reveal the higher concentrations of all the studied heavy metals recorded in roots of E. crassipes and T. angustata. The stems and/or leaves of submerged plants accumulate lower concentrations of trace elements than roots, which is well substantiated with the findings of Baldantoni et al. (2005). Thus among the studied plant species, E. crassipes and T. angustata appear to be the best monitoring species due to their availability in KCR.

The present study reveals that concentrations of the metals (in sediments and plant tissues) could be arranged in a decreasing order as follows: $\mathrm{Zn}>\mathrm{Cu}>\mathrm{Ni}>\mathrm{Cd}>\mathrm{Co}>$ $\mathrm{Pb}$. The decreasing order of the studied metals in KCR was based on the degree of toxicity status induced by them in both cases of plants and sediments: $\mathrm{Zn}>\mathrm{Cu}>\mathrm{Ni}$. The above sequence agrees with the findings of Ramdan (2003) and Siegel et al. (1994), who have worked on Lake Manzala, Nile Delta, Egypt. Also the ratio of these metals was two times higher in the sediments than in studied aquatic macrophytes. This agrees with previous findings of Ramdan (2003). Accordingly, the studied samples from KCR could be arranged in a decreasing order based on their content of heavy metals as follows: Sediment $>$ Root system $>$ Stem system $>$ Leaf system. Lovett-Doust et al . 
(1994) reported that the accumulation levels of pollutants in aquatic ecosystems may be higher in sediments than in plants. The high level of $\mathrm{Zn}$ and $\mathrm{Cu}$, an important source of contamination in the lake, might be due to agricultural run-off on soils around the reservoir, carrying various $\mathrm{Zn}$ and $\mathrm{Cu}$-based pesticides used by farmers in agricultural practices. This largely agrees with findings of Jones et al. (1991) for Lake Averno, and Siegel et al. (1994) for Ginka sub-basin, south of Lake Manzala.

\section{Conclusions}

Based on the above results, it was concluded that the three native aquatic plant species (Eichhornia, Vallisnaria and Typha spp.) accumulated heavy metals in much higher concentrations. Perhaps, it might be the reason that these three species are more efficient than the other native species in uptake of metals. Such aquatic macrophytes could also be used as 'active biomonitors' compared to other native aquatic macrophyte species (passive biomonitors).

Acknowledgements. We are grateful to "Charotar Ratna” and "Shalin Manav Ratna" Dr. C. L. Patel, Chairman, Charutar Vidya Mandal (CVM), Vallabh Vidynagar, Gujarat, India, for being a constant source of inspiration, initiation and motivation to carry out the work, without his initiative, this work would not have been possible. We are also thankful to Sophisticated Instrumentation Center for Applied Research and Testing (SICART), Vallabh Vidyanagar, Gujarat, India, for trace element analysis by Inductive Coupled Plasma Analyzer (ICPA).

\section{REFERENCES}

[1] Baldantoni D., Alfani A, Di Tommasi P., Bartoli G., De Santo A. (2004): Assessment of macro and microelement accumulation capability of two aquatic plants. Environmental Pollution, 130, 149-156.

[2] Baldantoni D., Maisto G., Bartoli G., Alfani A. (2005): Analyses of three native aquatic plant species to assess spatial gradients of lake trace element contamination. Aquatic Botany, 83, 48-60.

[3] Chaphekar S.B. (1991): An overview on bioindicators. Journal of Environmental Biology, 12, 163-168.

[4] De Bortoli M., Gaglione P., Malvicini A., Polvani C. (1968): Concentration factors for strontium and caesium in fish of the lakes in the region of Varese (Northern Italy). Giorn. Fisica Sanit. Radioprot. 12, 324-331.

[5] GSFD (2005): Six wetlands now at par with Chilka. A Proposition by Chief Wildlife Warden, Gujarat State Forest Department, Gandhinagar, Gujarat.

[6] Jackson L.J. (1998): Paradigms of metal accumulation in rooted aquatic vascular plants. Science of Total Environment 219, 223-231.

[7] Jones R., Chambers F.M. \& Benson-Evans K. (1991): Heavy metals (Cu and Zn) in recent sediments of Ilangrose Lake, Wales: non-ferrous smelting, Napoleon and the price of wheat - a plaeoecological study. Hydrobiologia, 214, 149-154.

[8] Kabata-Pendias A., Pendias H. (1992): Trace Elements in Soils and Plants. 2nd edn. CRC Press. Boca Raton, Fla.

[9] Koning F.J., Koning-Raat M.J. (1975): IWRB Mission to India. January / February 1975. International Waterfowl Research Bureau. Unpublished Report.

[10] Lovett-Doust J., Schmidt M., Lovett-Doust L. (1994): Biological assessment of aquatic pollution: A review with emphasis on plants as biomonitors. Biological Review, 69, 147186. 
[11] MoEF (2005): Gujarat: Six new 'Wetlands of National Importance'. Protected Area Update, 54, 6.

[12] Nirmal Kumar J.I., Kumar R.N. (1997): Elemental composition of certain economic important plants by EDAX. Proceedings of National Symposium on Plant Morhogenesis, pp.177-181.

[13] Nirmal Kumar J.I., Kumar, R.N., Soni H., Bhatt I. (2004): Distribution and Characterization of Heavy Metals of Vegetable Plants in and around Anand, Gujarat. Technical Report submitted to Charutar Vidya Mandal, Vallabh Vidyanagar, Gujarat, India. 1- 39.

[14] Nirmal Kumar J.I., Sreenivas S., Rana B.C. (1989): EDAX- analysis of mud of four ponds from Central Gujarat. Indian Botanical Contractor, 75-76.

[15] Pip E., Stepaniuk J. (1992): Cadmium, copper and lead in sediments and aquatic macrophytes in the Lower Nelson River System., Manitoba, Canada. I. Interspecific differences and macrophyte - sediment relations. Archive fur Hydrobiologie, 124, 337355.

[16] Ramdan A.A. (2003): Heavy metal pollution and biomonitoring plants in Lake Manzala, Egypt. Pakistan Journal of Biological Sciences, 6 (13), 1108-1117.

[17] Rana, B.C., Nirmal Kumar J.I. (1988): Energy Dispersal Analysis of X-rays of certain aquatic macrophytes. Indian Journal of Weed Science, 20, 46-49.

[18] Ravera O., Cenci R., Beon G.M., Dantas M., Lodigiani P. (2003) Trace element concentrations in freshwater mussels and macrophytes as related to those in their environment. Journal of Limnology, 62 (1), 61-70.

[19] Saison C., Schwartz C., Morel J.L. (2004): Hyperaccumulation of metals by Thlaspi caerulescens as affected by root development and $\mathrm{Cd}-\mathrm{Zn} / \mathrm{Ca}-\mathrm{Mg}$ interactions. International Journal of Phytology, 6 (1), 49-61.

[20] Scott R. (1989): The Asian Directory of Wetlands. (IUCN) Glands, Switzerland.

[21] Shah G.L. (1978): Flora of Gujarat State. Vols. I \& II. University Press. S. P. University. Vallabh Vidyanagar, Gujarat, India.

[22] Siegel F.R., Slaboda M.I., Stanely D.J. (1994): Metal pollution loading, Manzalah lagoon, Nile delta, Egypt: Implications for aquaculture. Environmental Geology, 23, 8998.

[23] Sinicrope T.L., Langis R., Gersberg R.M., Busnardo M.J., Zedler J.B. (1992): Metal removal by wetland mesocosms subjected to different hydroperiods. Ecological Engineering, 1, 309-322.

[24] St-Cyr L., Campbell P.G.C. (2000): Bioavailability of sediment-bound metals for Vallisneria americana Michx, a submerged aquatic plant, in the St. Lawrence River. Canadian Journal of Fishery Aquatic Sciences, 57, 1330-1341.

[25] Van Der Ven J. (1987): Asian Waterfowl 1987: Midwinter Bird Observations in some Asian Countries. Slimbridge. IWRB. 